\title{
In-situ measurement of the strength of deforming subglacial till
}

\author{
Neal R. Iverson, Peter Jansson and Roger LeB. Hooke \\ Department of Geology and Geophysics, University of Minnesota, Minneapolis, Minnesota 55455, U.S.A.
}

\begin{abstract}
The shear strength of deforming till beneath Storglaciären, Sweden, was continuously measured with a new instrument, a "dragometer". A cylinder with conical ends, roughened with till from the glacier bed, was dragged through the till, and the force on the cylinder was recorded. Consistent with studies of cone penetration in soils, it was assumed that the till behaves as a Coulomb plastic material. This allows the residual strength of the till to be calculated from the measured force. Results from laboratory experiments confirm the validity of the analytical procedure.

The average residual strength of the till was $\sim 55 \mathrm{kPa}$. A source of error is the potential generation of pore pressure in excess of hydrostatic ahead of the cylinder, which could significantly weaken the till. Calculations indicate that excess pore pressure did not develop during the experiment, but could develop during similar experiments beneath rapidly sliding glaciers with less permeable basal till layers.
\end{abstract}

\section{INTRODUGTION}

Highly disparate constitutive relations have been proposed for sediment deformation beneath glaciers (e.g. Alley and others, 1987; Boulton and Hindmarsh, 1987; Kamb, 1991). None has gained widespread acceptance due to a lack of reliable field measurements and appropriately configured laboratory experiments.

Blake and others (1992) presented novel down-hole techniques for the measurement of shear strain in a subglacial sediment layer. As a complement to deformation measurements, continuous measurements of the shear stress that ice exerts on the upper surface of such a layer are needed. Estimates based on glacier geometry are unsatisfactory, as they yield only spatial and temporal averages. Thus, as an alternative, efforts have been directed at measuring the sediment strength by inserting an instrument into sediment at the bottom of a borehole. Humphrey and others (1993) and Fischer and Clarke (1994) determined the force on a long cylinder fixed at the base of a borehole and ploughing through the deforming bed. By assuming that the sediment deformed as an ideal plastic, they arrived at estimates of the yield strength. They also considered a Newtonian viscous rheology and were able to estimate the apparent viscosity of the sediment.

Any technique for measuring the strength of sediment beneath glaciers should ideally satisfy a number of criteria, some of which are quite restrictive:

1. The technique should draw upon extensive theoretical and empirical developments from geotechnical engineering on in-situ testing of sediment.

2. Any assumed rheology for the sediment should explicitly include the important influence of effective pressure on strength.
3. The measurement should be made in sediment some distance from the base of the borehole. Steep gradients in effective normal stress are expected beneath the edges of the borehole because the iceoverburden pressure there is zero and because the pore pressure there is likely to be perturbed. These problems make standard down-hole methods for measuring sediment strength, such as penetrometer and vane-shear tests, undesirable, particularly when the borehole diameter is a significiant fraction of the sediment-layer thickness.

4. The measuring device should not perturb the ambient pore-water pressure in the sediment, or alternatively, if the pore pressure is perturbed, it should be measured or estimated and factored into the data reduction.

Here, a technique is presented that, to a large extent, satisfies these criteria. Initial results are reported that are part of a more comprehensive data set on basal till deformation gathered at Storglaciären. The till is considered to be a granular material in which resistance to deformation is controlled by intergranular friction. This is a particularly good assumption for the till beneath Storglaciären, which contains little clay and consists mostly of coarse silt and fine sand, like most tills developed on crystalline bedrock in Scandinavia and North America (Dreimanis and Vagners, 1971; Scott, 1976; Jorgesen, 1977; Haroldsen, 1981).

\section{METHOD}

\section{Instrument design}

As in other studies (Humphrey and others, 1993; Fischer and Clarke, 1994), we sought to measure till strength by 


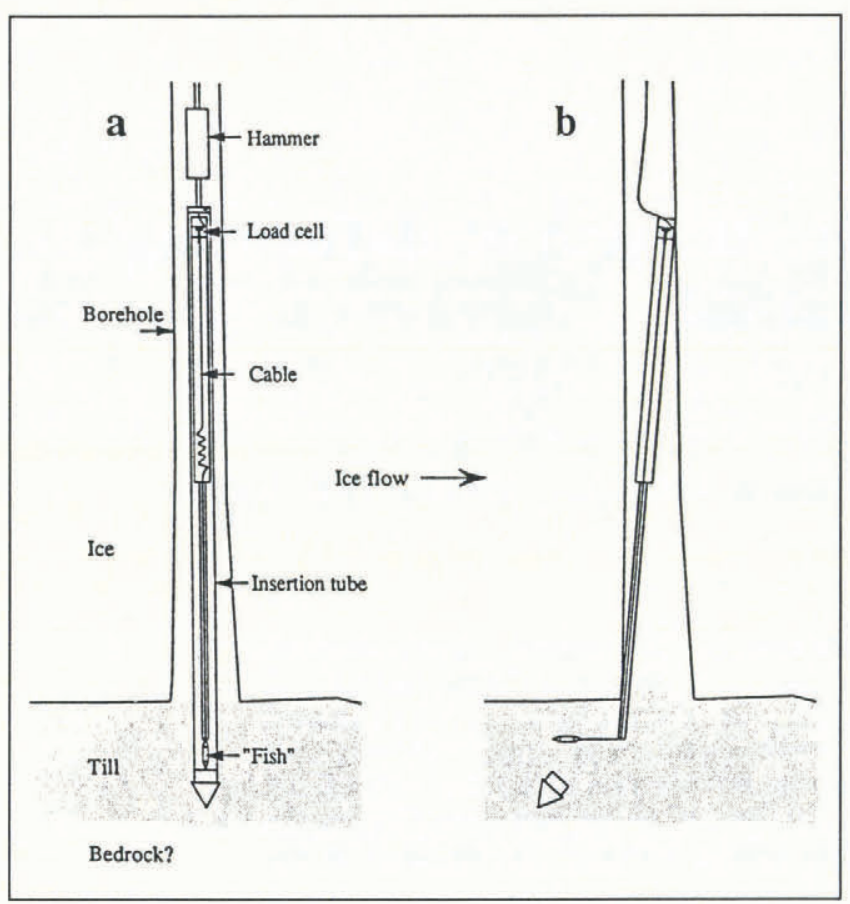

Fig. 1. Sketch of dragometer; (a) immediately after insertion and (b) in operation.

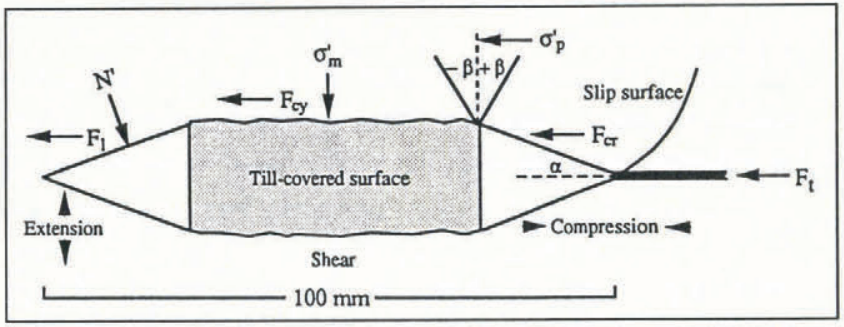

Fig. 2. Cross-section of fish moving from left to right through till. Slip surfaces lie approximately parallel to surface defined by $\beta$. Other parameters are discussed in the text and Appendix.

dragging an object through the till and measuring the force on the object. Our device (Fig. 1), hereafter referred to as a "dragometer", consists of a steel cylinder with conical ends, dubbed the "fish", that is dragged through the till by a $1.9 \mathrm{~m}$ long steel pipe. The fish is $100 \mathrm{~mm}$ long

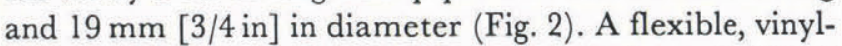
covered aircraft cable with a diameter of $1.6 \mathrm{~mm}$ [1/16 in] runs from the fish up through the bottom of the pipe to a load cell that is housed in a separate module in the pipe's upper end. The module is filled with mineral oil to prevent penetration of water into the load cell. The pipe and fish are lowered down a borehole and driven into the bed with a percussion hammer and insertion tube similar to that used by Blake and others (1992) (Fig. 1a). After insertion, the hammer and tube are withdrawn leaving the pipe and fish embedded in the till. Eventually, owing to the glacier motion, the pipe jams in the bottom of the borehole. After several days of bed deformation, probably together with sliding at the ice-till interface, the cable becomes taut and the fish begins moving through the till (Fig. 1b). The instrument is calibrated by fixing the pipe horizontally and hanging weights on the cable at a rightangle to the pipe axis.
The cable length was adjusted so that the fish was dragged $100 \mathrm{~mm}$ behind the base of the pipe, which was $19 \mathrm{~mm}$ in diameter. This length was sufficient to position the fish beneath the ice, rather than beneath the borehole, but was short enough to provide an acceptably small time between insertion and the beginning of the experiment. Whether this distance was large enough to insure that the disturbance caused by the ploughing pipe did not significantly affect the force on the fish is assessed later.

\section{Theory}

It is well established that granular materials have a yield strength, $\tau$, at which they begin to deform irrecoverably. This strength is typically expressed by the Coulomb failure criterion:

$$
\tau=c+\sigma^{\prime} \tan \phi
$$

where $c$ is the cohesion, $\phi$ is the angle of internal friction, $\sigma^{\prime}$ is the effective normal stress (the difference between the total normal stress and the pore pressure) acting on the zone of failure. Dilation of sediment as it begins to shear results in a reduction of the apparent friction angle. This effect is complemented by the alignment of platy clay minerals during shearing. After shearing displacements that vary from several millimeters to several meters, the sediment volume and friction angle become steady (e.g. Skempton, 1985). At this point, the sediment is said to have reached its residual state and to have a residual friction angle, $\phi_{\mathrm{r}}$. There is no cohesion in the residual state (Mitchell, 1976, p.313; Head, 1982, p. 532). It is this residual strength of the deforming sediment that we wish to measure.

The shear stress supported along a shear plane through the sediment depends on the friction between grains and the extent of grain interlocking (Lambe and Whitman, 1969, p. 130). In order to simulate this friction and interlocking, till from beneath Storglaciären, excluding grains larger than $2 \mathrm{~mm}$, was cemented to the cylindrical part of the fish (Fig. 2). Therefore, the shear force supported by the cylinder sides divided by the surface area of the cylinder should approximate the till's residual strength.

A significant fraction of the total (measured) force on the fish, however, is exerted on its leading end. Thus, the partitioning of the force between the leading cone and the sides of the fish must be determined. This problem has been studied extensively by engineers concerned with calibration of cone penetrometers. Such instruments are used in drillholes to provide estimates of the mechanical properties of on- and offshore sediments (see Ruiter (1982) for a review).

The force on the leading end depends on a number of factors, and no single theory yet addresses all of these without some empiricism. Most importantly, it depends on the composition and rheology of the till. The till rheology is complicated by the compressibility of granular materials and the influence of the effective normal stress. In addition, forces measured in penetrometer tests depend sensitively on the penetrometer roughness (Durgunoglu and Mitchell, 1974).

Consistent with studies of cone penetration, we assume that the sediment behaves as a Coulomb plastic material. 
Like an ideal (Mises) plastic, the strength is independent of the deformation rate. In addition, the strength is explicitly formulated in terms of the effective normal stress (Equation (1)). This model is well suited to studies of sediment deformation in which intergranular friction provides most or all of the resistance to deformation in the residual state. Indeed, it is the classic model on which most geotechnical work and many models of landslide behaviour are based (e.g. Savage and Smith, 1986; Baum and Fleming, 1991).

Consider deformation around the leading cone as the fish ploughs forward (Fig. 2). There is a zone of compression where plastic deformation occurs. Empirical studies show that the shape and size of this zone vary with grain-size distribution, sediment consolidation, cone roughness and cone angle, $\alpha$. The angle $\beta$ defines a surface that lies approximately parallel to slip surfaces within the zone of compression. Experiments with cones, plates and piles indicate that it varies from $+15^{\circ}$ in compressible, fine sediment to $-30^{\circ}$ in compact, coarsegrained sediment (Janbu and Senneset, 1974; Senneset and Janbu, 1985). We will assume that $\beta=+15^{\circ}$ because basal tills should be compressible in the residual state and are typically dominated by silt and fine sand, like the till beneath Storglaciären.

The force, $F_{\mathrm{c}}$, on the leading end is given by

$$
F_{\mathrm{c}}=A_{\mathrm{c}}\left[N_{\mathrm{F}}\left(\sigma_{\mathrm{p}}^{\prime}+C_{\mathrm{a}}\right)-C_{\mathrm{a}}\right]
$$

where $A_{\mathrm{c}}$ is the cross-sectional area of the cone, $\sigma_{\mathrm{p}}^{\prime}$ is the effective stress in the direction of the fish axis, $C_{\mathrm{a}}$ is called the "attraction" and is equal to $c / \tan \phi_{\mathrm{r}}$, and $N_{\mathrm{F}}$ is a bearing-capacity factor (Janbu and Senneset, 1974; Senneset and others, 1982; Senneset and Janbu, 1985). A simple expression for $N_{\mathrm{F}}$ in plane strain that agrees reasonably well with experiments using cones, plates and piles is

$$
N_{\mathrm{F}}=\tan ^{2}\left(45^{\circ}+\phi / 2\right) \mathrm{e}^{(\pi-2 \beta) \tan \phi}
$$

(Janbu and Senneset, 1974). For deforming till in its residual state, $\phi=\phi_{\mathrm{r}}$, and there is no cohesion, so $C_{\mathrm{a}}$ should be zero. Thus, substituting Equation (3) into Equation (2), the bed-parallel force on the leading cone for till in the residual state, $F_{\mathrm{cr}}$, is given by

$$
F_{\text {cr }}=A_{\mathrm{c}} \sigma_{\mathrm{p}}^{\prime} \tan ^{2}\left(45^{\circ}+\phi_{\mathrm{r}} / 2\right) \mathrm{e}^{(\pi-2 \beta) \tan \phi_{\mathrm{r}}} .
$$

The force supported parallel to the roughened sides of the cylindrical part of the fish, $F_{\mathrm{cy}}$, is given by

$$
F_{\text {cy }}=A_{\text {cy }} \sigma_{\mathrm{m}}^{\prime} \tan \phi_{\mathrm{r}}
$$

where $A_{\text {cy }}$ is the surface area of the cylinder, and $\sigma_{\mathrm{m}}^{\prime}$ is the mean effective normal stress acting on the cylinder.

A good approximation is to neglect the force, $F_{1}$, on the trailing cone (Appendix), leaving the total bedparallel force, $F_{t}$, equal to the sum of Equations (4) and (5). Effective stresses in the till are probably not isotropic, but without information to the contrary, it is assumed that $\sigma^{\prime}=\sigma_{\mathrm{p}}^{\prime}=\sigma_{\mathrm{m}}^{\prime}$. Dividing Equation (5) by the sum of Equations (4) and (5) gives the fraction of the total force on the fish that is supported along its sides, $\kappa$ :

$$
\kappa=\left[1+\frac{A_{\mathrm{c}} \tan ^{2}\left(45^{\circ}+\frac{\phi_{\mathrm{r}}}{2}\right) \mathrm{e}^{(\pi-2 \beta) \tan \phi_{\mathrm{r}}}}{A_{\text {cy }} \tan \phi_{\mathrm{r}}}\right]^{-1} .
$$

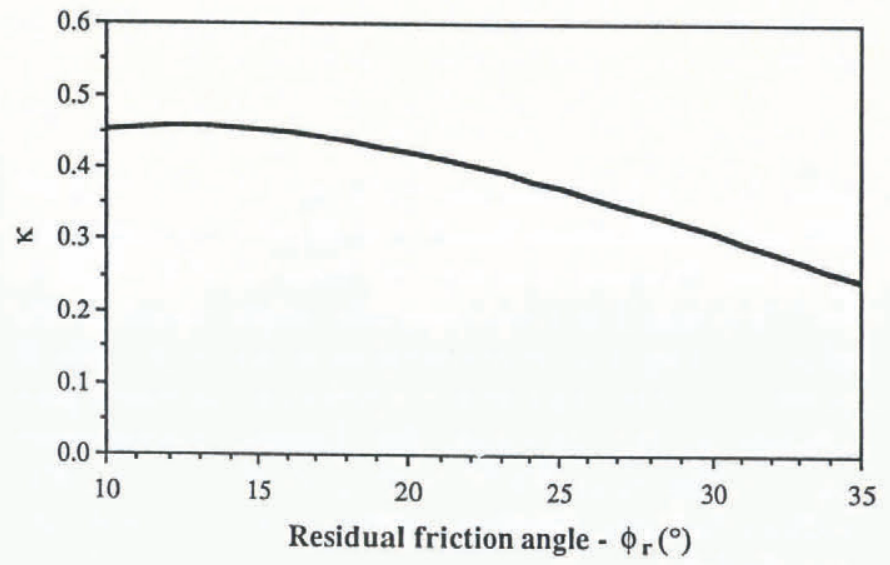

Fig. 3. $\kappa$ as a function of residual friction angle.

Using $\kappa$ and the measured value of $F_{\mathrm{t}}$, the residual strength, $\tau_{\mathrm{r}}$, and the effective normal stress can be determined from

$$
\begin{aligned}
\tau_{\mathrm{r}} & =F_{\mathrm{t}} \kappa / A_{\mathrm{cy}} \\
\sigma^{\prime} & =F_{\mathrm{t}} \kappa / A_{\mathrm{cy}} \tan \phi_{\mathrm{r}} .
\end{aligned}
$$

Figure 3 illustrates how $\kappa$ varies through the potential range of residual friction angle.

To some extent, $\phi_{\mathrm{r}}$ can be estimated from the sediment composition. For example, for sediment that contains less than $25 \%$ clay, $\phi_{\mathrm{r}}$ should typically be greater than $20^{\circ}$ (Skempton, 1985). A better alternative is to measure $\phi_{\mathrm{r}}$ in laboratory tests. We conducted a series of drained direct-shear tests (Head, 1982, p. 509-71) on till collected from the bed of Storglaciären. The test yielded a peak friction angle of $31^{\circ}$ and a cohesion of $5 \mathrm{kPa}$. Although the geometry of the test cell limited the shearing displacement to about $80 \mathrm{~mm}$, the samples contained no clay and were normally consolidated. Under these conditions, there is generally no post-peak reduction in strength observed in experiments carried out to large strains (Lambe and Whitman, 1969; Skempton, 1985). Thus, a good assumption is that $\phi_{\mathrm{r}}=31^{\circ}$, which yields $\kappa=0.30$.

\section{Excess pore pressure}

Our technique, as well as others (Humphrey and others, 1993; Fischer and Clarke, 1994), is only appropriate when subglacial sediment is sufficiently permeable that compression in front of the ploughing object does not result in pore pressure in excess of hydrostatic pressure. In practice, during cone-penetration tests on impermeable sediments such as clay and silt, excess pore pressure does tend to develop adjacent to the cone and shaft, and this may weaken the sediment by an order of magnitude (e.g. Campanella and others, 1983; Senneset and Janbu, 1985). The standard rate of cone penetration in such tests, however, is $0.02 \mathrm{~m} \mathrm{~s}^{-1}$ (Campanella and others, 1983), which is orders of magnitude faster than rates of glacier sliding. It is, therefore, uncertain whether excess pore pressure might develop in till adjacent to the fish.

In order to investigate this problem, we follow scaling arguments by Rudnicki (1984) and Iverson and LaHusen (1989) and calculate a dimensionless parameter, $R$, which depends on the relative rates at which the grain skeleton is 
compressed and at which pore pressure diffusively dissipates:

$$
R=k / V \chi \mu \delta
$$

Here, $k$ is the hydraulic permeability of the till, $V$ is the fish velocity relative to the till, $\chi$ is the till compressibility, $\mu$ is the dynamic viscosity of water at $0^{\circ} \mathrm{C}(1.78 \times$ $10^{-3} \mathrm{Pas}$ ) and $\delta$ is a characteristic length, equal to the diameter of the zone of compression in front of the fish. $R$ is the ratio of the time-scale for generation of excess pore pressure to the time-scale for diffusive pore-pressure equilibration across $\delta\left(\delta / V\right.$ to $\left.\delta^{2} \mu \chi / k\right)$. Thus, when $R$ is sufficiently large, significant excess pore pressure should not develop.

Such scaling arguments are most useful if the threshold value or range of values for $R$ can be determined from experiments in which all relevant parameters are known. Campanella and others (1983) presented the results of a cone-penetration test on a silty clay in which the rate of cone penetration was systematically varied and excess pore pressure was recorded by a transducer in the cone. Their data suggest that significant excess pore pressure developed at a velocity of the order of $10^{-4} \mathrm{~m} \mathrm{~s}^{-1}$. Other parameters were $k=8 \times 10^{-16} \mathrm{~m}^{2}, \delta \sim 0.05 \mathrm{~m}$ and $\mu=1.1 \times 10^{-3} \mathrm{Pas}$. They did not report the sediment compressibility; a reasonable range is $10^{-6}-10^{-8} \mathrm{~Pa}^{-1}$ (Freeze and Cherry, 1979, p.55; Head, 1982, p.683). Inserting these values in Equation (8) yields a threshold range for $R$ of $0.15-15$. Thus, a good assumption is that when $R \gg 15$ excess pore pressure should not develop ahead of the fish.

Empirical studies of sediment deformation beneath cone penetrometers (e.g. Malyshev and Lavisin, 1974; Koumoto and Kaku, 1982) suggest that $\delta=0.02 \mathrm{~m}$ is a good approximation for our fish. Several tests with a falling-head permeameter on till samples collected from beneath Storglaciären yielded $k=1.3 \times 10^{-14} \mathrm{~m}^{2} . V$ cannot exceed the surface velocity, which on Storglaciären seldom exceeds $0.1 \mathrm{~m} \mathrm{~d}^{-1}$ during the summer. The compressibility of the till beneath the glacier has not been measured; we choose a maximum value of $1 \times$ $10^{-6} \mathrm{~Pa}^{-1}$ in order to minimize $R$. Using these values in Equation (8) shows that $R$ exceeds 315 for experiments on the till beneath Storglaciären, indicating that pore pressure adjacent to the fish did not exceed hydrostatic pressure.

However, on glaciers with less permeable subglacial sediment and higher sliding velocities, the time-scales for the generation and dissipation of excess pore pressure may be of the same order. For example, for the sediment beneath Ice Stream B, Antarctica, $k=2 \times 10^{-16} \mathrm{~m}^{2}$, and $V$ may approach $2.3 \mathrm{~m} \mathrm{~d}^{-1}$ (Engelhardt and others, 1990). In this case, $R$ ranges from 0.21 to 21 for $10^{-6}>\chi>$ $10^{-8} \mathrm{~Pa}^{-1}$. Therefore, excess pore pressure may develop and would need to be measured or estimated.

\section{Laboratory tests}

In an effort to evaluate the theory, laboratory tests were conducted in which the fish was dragged through till collected from Storglaciären. The till was dry and was confined within a $0.28 \mathrm{~m} \times 0.14 \mathrm{~m} \times 0.16 \mathrm{~m}$ box. A normal stress was exerted on the upper surface of the

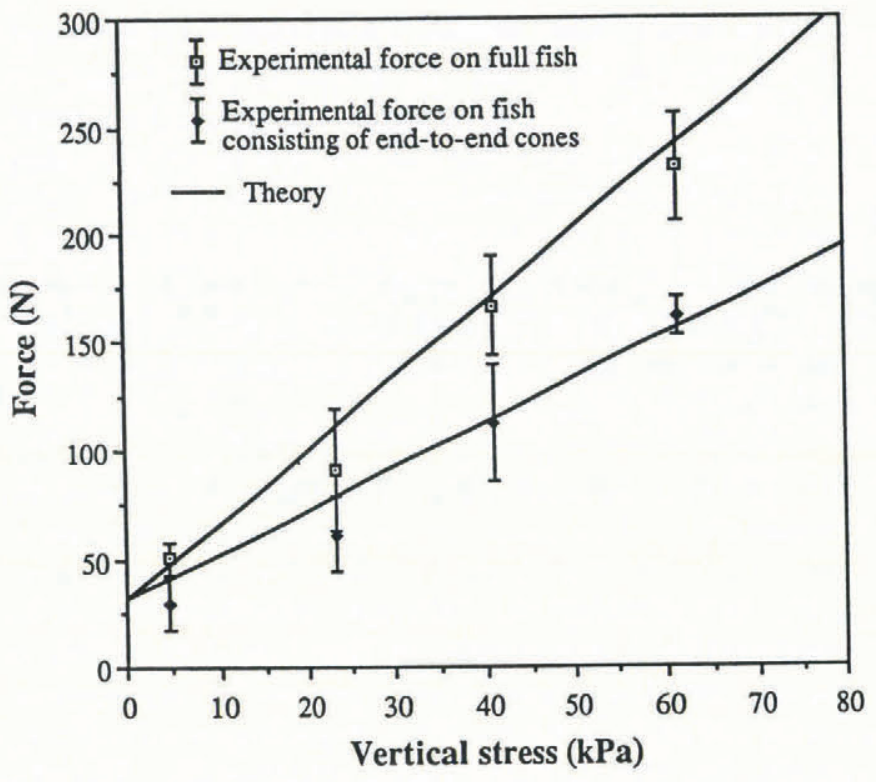

Fig. 4. Experimental and theoretical values for force on full fish and force on fish consisting of end-to-end cones, as a function of vertical stress. Each experimental value is the mean of four measurements. Error bars show \pm 1 standard deviation.

till by a platen loaded with weights, while the fish was dragged horizontally along the long dimension of the box. A second fish consisting of end-to-end cones was also used to study forces on the fish ends alone. Results from 16 experiments with each fish type are plotted in Figure 4.

The experimental conditions differed from those at a glacier bed in several ways. In the experiments, the till was not deforming independently of the fish motion, and thus it was not necessarily in the residual state. Therefore, cohesive forces may have been operating in the zone of compression in front of the fish. Along the fish sides, no cohesion was expected because minute particles responsible for cohesive forces should have been effectively submerged in the epoxy resin used for cementation. The theoretical force on the full fish, therefore, was calculated by adding Equations (2) and (5). A further complication is that effective stresses were not isotropic in the experiments. It is well established that when sediment is loaded vertically in confined compression for the first time, the horizontal stress $\sigma_{\mathrm{h}}$ is less than the vertical stress $\sigma_{\mathrm{v}}$. A relation that fits most experimental values was suggested by Jáky (1944) (in Lambe and Whitman 1969, p. 127):

$$
\sigma_{\mathrm{h}}=\sigma_{\mathrm{v}}(1-\sin \phi) \text {. }
$$

This relation was used to determine $\sigma_{\mathrm{p}}^{\prime}\left(=\sigma_{\mathrm{h}}\right)$ and $\sigma_{m}^{\prime}\left(=\left[\sigma_{\mathrm{h}}+\sigma_{\mathrm{v}}\right] / 2\right)$ from the vertical load on the till. Finally, it was assumed that $\phi=31^{\circ}$ and $c=5 \mathrm{kPa}$, based on the direct-shear results.

The theory approximates the measured force on the fish relatively well (Fig. 4). Although the laboratory till was dry, its behavior would not be significantly different if it were water-saturated, but drained well enough so that excess pore pressure did not develop (Lambe and Whitman, 1969, p. 295). Thus, these experiments demonstrate that the theory adequately approximates the total force on the fish and the force on the fish ends. Therefore, 
values of $\kappa$ calculated from Equation (6) can be used with some confidence in Equations (7) to estimate the residual strength and local effective normal stress from the measured force on the fish.

\section{RESULTS FROM STORGLAGIÄREN}

The dragometer was used to study the residual strength of till beneath $95 \mathrm{~m}$ of ice in the ablation area of Storglaciären. Tiltmeters inserted in this till demonstrate that it is actively shearing (Iverson and others, 1992). Prior to installing the instrument, a penetrometer was driven into the till, which yielded a minimim till thickness of $0.35 \mathrm{~m}$. The depth of fish emplacement is difficult to determine accurately due to possible settling of the insertion assembly into the till prior to hammering. However, the penetration caused by hammering can be measured with a precision of approximately $0.01 \mathrm{~m}$. This measurement indicated an initial minimum depth of travel for the fish of $0.06 \mathrm{~m}$.

The raw data (Fig. 5) show that the signal from the dragometer changed immediately after insertion. This is partly a temperature-related effect caused by submerging the load cell in water at $0^{\circ} \mathrm{C}$. Some of the change probably reflects tension on the cell resulting from friction between sediment and the cable. The cable was observed to fall out of the end of the pipe under its own weight as the dragometer was prepared for insertion. Thus, a

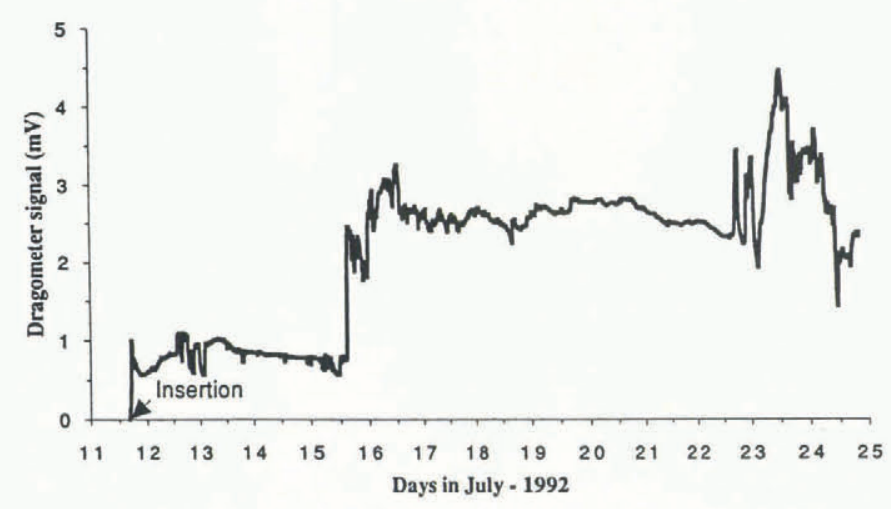

Fig. 5. Dragometer signal. Rapid increase on 15 July 1992 is inferred to be when cable became taut and fish began ploughing through till.

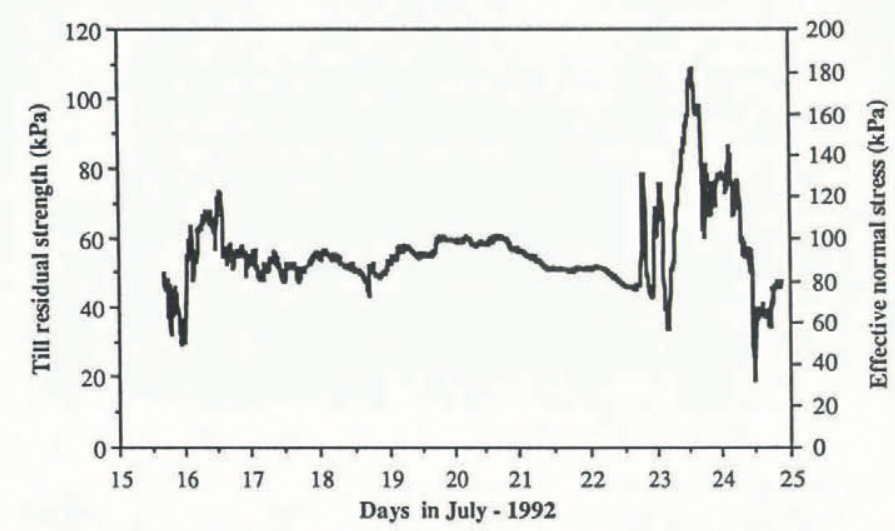

Fig. 6. Residual strength of till and effective normal stress calculated from measured force on fish. fraction of the exposed cable may have tightened due to friction along its length prior to tightening of the full cable length. Assuming a friction coefficient of 1.0 and an effective normal stress on the full cable length of $100 \mathrm{kPa}$ yields friction equivalent to about $0.35 \mathrm{mV}$ in Figure 5.

Four days after insertion, there was a rapid increase in the load-cell signal (Fig. 5). The increase is inferred to represent the tightening of the cable as the fish began to be dragged through the till. If this is correct, the relative velocity between the fish and the basal ice would have had to have been about $26 \mathrm{~mm} \mathrm{~d}^{-1}$ over this $4 \mathrm{~d}$ period, a speed that is consistent with the mean surface velocity, $42 \mathrm{~mm} \mathrm{~d}^{-1}$. The difference between these speeds presumably reflects deformation of ice and especially till.

The signal was converted to a force, $F_{\mathrm{t}}$, which was then substituted into Equations (7) to obtain the residual strength and the effective normal stress on the till (Fig. 6). $\kappa$ was calculated using a residual friction angle of $31^{\circ}$ and $\beta=15^{\circ}$.

The average residual strength of the sediment over the period of the measurement was approximately $55 \mathrm{kPa}$. This is about $60 \%$ of the winter basal shear stress, calculated from the driving stress by measuring lateral and longitudinal strain rates and applying a forcebalance model for the area just up-glacier from the site of the experiment (Hooke and others, 1989). The unsteady character of the record is similar to records obtained with cone penetrometers (e.g. McNeilan and Bungo, 1985; Senneset and Janbu, 1985). We interpret these apparent variations in strength, together with changes in the rate of shear strain measured in the till nearby and sub-hourly variations in glacier-surface velocity (unpublished work of B. Hanson), in a second paper in preparation.

\section{DISCUSSION AND GONGLUSIONS}

Like other in-situ determinations of the mechanical properties of basal till (Humphrey and others, 1993; Fischer and Clarke, 1994), ours requires that a specific till rheology be chosen. Numerous empricial studies of cone penetration through sand, silt and clay demonstrate that the Coulomb plastic model is reasonable (e.g. Durgunoglu and others, 1974; McNeilan and Bungo, 1985; Senneset and Janbu, 1985). In contrast, there is no comparable empiricial support for assuming Newtonian viscous flow around inclusions in granular materials, the other end member of the range of potential rheological behaviors that has been suggested for till deformation around inclusions (Humphrey and others, 1993; Fischer and Clarke, 1994). Studies of cone penetration also permit us to account approximately for several factors that are difficult to consider theoretically, including the grain-size distribution and the sediment compressibility. These factors are embodied in the angle $\beta$ in Equation (6) (Senneset and Janbu, 1985).

Nevertheless, measurements of shear deformation that are distributed across significant thicknesses of subglacial till (Boulton and Hindmarsh, 1987; Blake and others, 1992; Humphrey and others, 1993) suggest that till layers as a whole exhibit some viscous behavior. Owing to the wide range of grain-sizes, it is possible that localized 
deformation adjacent to the fish is essentially plastic, but that on a larger scale shear stresses exerted by the glacier sole induce deformation that is, to some extent, viscous. However, we cannot rule out the possibility that local till deformation around the fish was also viscous. In this case, the force on the fish would have depended on its speed relative to the till.

It is important to consider whether the pipe that drags the fish disturbs the till sufficiently to influence the measurement. Although the fish trailed the pipe by about five pipe diameters, it is possible that the original porosity of the till was not fully recovered from this disturbance when sampled by the fish. This would be a major concern if the till were not independently deforming. However, because the till was presumably dilated and in its residual state prior to the deformation induced by the pipe, we anticipate that this effect was minor.

Another consideration is that the fish may have traveled at variable depths in the till during the experiment. This could be caused by vertical motion of the ice or a change in the angle of the pipe in the borehole. Thus, the fish could have sampled different layers within the till, or in the worst case, could have lodged at the ice-till interface. We believe that the latter situation was unlikely, owing to the large amount of glacier uplift or pipe rotation required to lift the fish to glacier sole, $0.06 \mathrm{~m}$ or $20^{\circ}$, respectively.

The results from Storglaciären suggest that the basal till supports $\sim 55 \mathrm{kPa}$. Fischer and Clarke (1994) determined a yield strength of $48-57 \mathrm{kPa}$ for the deforming till beneath Trapridge Glacier. In contrast with these values, Humphrey and others (1993) obtained a yield strength of $5.5 \mathrm{kPa}$ for the sediment beneath Columbia Glacier by analyzing the deformation of a drill stem that was stuck at the base of a borehole. The difference in sediment strength could potentially be a function of differing sediment permeabilities related to composition. Less permeable sediment would allow the maintenance of higher pore-water pressures, thereby reducing strength. Alternatively, the lower strength may have resulted from excess pore pressure induced by the drill stem. The sliding velocity of Columbia Glacier is $3-4 \mathrm{~m} \mathrm{~d}^{-1}$, and the till permeability is not known. If $\delta$ in Equation (8) is $0.034 \mathrm{~m}$, equal to the diameter of the drill stem, and the sediment compressibility is constrained as before, then the timescales for loading of sediment in front of the stem and pore-pressure dissipation are of the same order $(R=1)$ if till permeabilities range from $3 \times 10^{-15}$ to $3 \times 10^{-17} \mathrm{~m}^{2}$. These permeabilities are at the center of the range of values for till provided by Freeze and Cherry (1979, p.29). Thus, excess pore pressure induced by the drill stem cannot be precluded.

The difference between the strength of the till beneath Storglaciären and the winter basal shear stress could be due to several factors. For example, in the upper part of the ablation area, force-balance calculations indicate that the basal shear stress decreases during periods of high velocity during the summer (Hooke and others, 1989). These periods are associated with high water inputs to the glacier, suggesting that the effective pressure on the till may be reduced during such periods. A second possible explanation is that the glacier may be supported, in part, by bedrock bumps. Occasionally, we are unable to penetrate or sample the bed, indicating that some subglacial bedrock is indeed free of till. In contrast with results from the upper ablation area, force-balance calculations for the lower ablation area (Hooke and others, 1989), slightly up-glacier from the site of the present experiment, showed that the basal shear stress increased during periods of high velocity. This apparent viscous behavior is consistent with sliding over rigid bumps on the bed. It may also be significant that the dragometer experiment and the measurements used for input to the force-balance calculation were made during different years and at slightly different locations in the ablation area.

An obvious improvement in the dragometer would be the installation of a miniature pore-pressure transducer within the fish. Such transducers are standard in many cone penetrometers (Ruiter, 1982) and greatly increase the quality of data gathered in poorly drained sediments. The leads for the transducer would require connecting the fish to the load cell with a thin armored electrical cable rather than an aircraft cable. We plan to test this modification in future experiments on Storglaciären.

\section{ACKNOWLEDGEMENTS}

This research was supported by the U.S. National Science Foundation (grant DPP-8822156) and by the Swedish Natural Resources Research Council. We would be remiss if we did not acknowledge our debt to G. Clarke and his students whose imaginative instrumentation for the in-situ study of subglacial till has inspired our efforts. We thank E. Blake, U. Fischer, R. Iverson and J. Walder for helpful reviews of the manuscript.

\section{REFERENCES}

Alley, R. B., D. D. Blankenship, C. R. Bentley and S. T. Rooney. 1987. Till beneath Ice Stream B. 3. Till deformation: evidence and implications. 7. Geophys. Res., 92(B9), 8921-8929.

Baum, R.L. and R.W. Fleming. 1991. Use of longitudinal strain in identifying driving and resisting elements in landslides. Geol. Soc. Am. Bull., 103, 1121-1132.

Blake, E., G. K. C. Clarke and M. C. Gérin. 1992. Tools for examining subglacial bed deformation. F. Glaciol., 38(130), 388-396.

Boulton, G.F. and R. C. A. Hindmarsh. 1987. Sediment deformation beneath glaciers: rheology and geological consequences. F. Geophys. Res., 92(B9), 9059-9082.

Campanella, R. G., P. K. Robertson and D. Gillespie. 1983. Cone penetration testing in deltaic soils. Can. Geotech. J., 20(1), 23-35.

Dreimanis, A. and U.J. Vagners. 1971. Bimodal distribution of rock and mineral fragments in basal tills. In Goldthwait, R.P., ed. Till-a symposium. Columbus, OH, Ohio State University Press, 237-250.

Durgunoglu, H. T. and J.K. Mitchell. 1974. Influence of penetrometer characteristics on static penetration resistance. In Broms, B. B., ed. Proceedings of the European Symposium on Penetration Testing, Stockholm, Sweden, June 5-7, 1974. Vol. 2(2). Stockholm, National Swedish Building Research, 133-140.

Engelhardt, H., N. Humphrey, B. Kamb and M. Fahnestock. 1990. Physical conditions at the base of a fast moving Antarctic ice stream. Science, 248(4951), 57-59.

Fischer, U.H. and G. K.C. Clarke. 1994. Ploughing of subglacial sediment. J. Glaciol., 40(134), 97-106.

Freeze, R. A. and J. A. Cherry. 1979. Groundwater. Englewood Cliffs, NJ, Prentice-Hall.

Haldorsen, S. 1981. Grain-size distribution of subglacial till and its relation to glacial crushing and abrasion. Boreas, 10(1), 91-105.

Head, K. H. 1982. Manual of soil laboratory testing. Volume 2. Permeability, shear strength, and compressibility tests. New York, John Wiley and Sons.

Hooke, R. LeB., P. Calla, P. Holmlund, M. Nilsson and A. Stroeven. 
1989. A 3 year record of seasonal variations in surface velocity, Storglaciären, Sweden. F. Glaciol., 35(120), 235-247.

Humphrey, N., B. Kamb, M. Fahnestock and H. Engelhardt. 1993. Characteristics of the bed of the lower Columbia Glacier, Alaska. $\mathcal{J}$. Geophys. Res., 98(B1), 837-846.

Iverson, R. M. and R.G. LaHusen. 1989. Dynamic pore-pressure fluctuations in rapidly shearing granular materials. Science, 246, 796-799.

Iverson, N. R., P. Jansson, R. LeB. Hooke and B. Hanson. 1992. Direct measurement of the shear strength and deformation of till beneath Storglaciären, N. Sweden. EOS, 73(43), 160.

Jáky, J. 1944. The coefficient of Earth pressure at rest. F. Soc. Hung. Archit. Eng., 78, 355-358.

Janbu, N. and K. Senneset. 1974. Effective stress interpretation of in-situ static penetration tests. In Broms, B. B., ed. Proceedings of the European Symposium on Penetration Testing, Stockholm, Sweden, June 5-7, 1974. Vol. 2(2). Stockholm, National Swedish Building Research, 181-194.

Jørgensen, P. 1977. Some properties of Norwegian tills. Boreas, 6(2), 149-157.

Kamb, B. 1991. Rheological nonlinearity and flow instability in the deforming bed mechanism of ice stream motion. F. Geophys. Res., 96(B10), 16,585-16,595.

Koumoto, T. and K. Kaku. 1982. Three-dimensional analysis of static cone penetration into clay. In Verruijt, A., F. L. Beringen and E. H. de Leeuw, eds. Penetration testing. Proceedings of the Second European Symposium on Penetration Testing, Amsterdam, May 24-27, 1982. Vol. 2. Rotterdam, A. A. Balkema, 635-640.

Lambe, T.W. and R. V. Whitman. 1969. Soil mechanics. New York, Wiley and Sons.

McNeilan, T. W. and W. T. Bugno. 1985. Cone penetration test results in offshore California silts. In Chaney, R. C. and K. R. Demars, eds. Strength testing of marine sediments: laboratory and in-situ measurements. Philadelphia, PA, American Society for Testing and Materials, 55-71. (Special Technical Publication 883.)

Malyshev, M.V. and A.A. Lavisin. 1974. Certain results obtained in cone penetration of a sand base. In Broms, B. B., ed. Proceedings of the European Symposium on Penetration Testing, Stockholm, Sweden, June 5-7, 1974. Vol. 2(2). Stockholm, National Swedish Building Research, 237-239.

Mitchell, J. K. 1976. Fundamentals of soil behavior. New York, Wiley and Sons.

Rudnicki, J. W. 1984. Effects of dilatant hardening on the development of concentrated shear deformation in fissured rock masses. F. Geophys. Res., 89(B11), 9259-9270.

Ruiter, J. de. 1982. The static cone penetration test: state-of-the-art report. In Verruijt, A., F.L. Beringen and E.H. de Leeuw, eds. Penetration testing. Proceedings of the Second European Symposium on Penetration Testing, Amsterdam, May 24-27, 1982. Vol. 2. Rotterdam, A. A. Balkema, 389-405.
Savage, W. Z. and W. K. Smith. 1986. A model for the plastic flow of landslides. U.S. Geol. Surv. Prof. Pap. 1385, 1-32.

Scott, J. S. 1976. Geology of Canadian tills. In Legget, R. F., ed. Glacial till - an interdisciplinary study. Ottawa, Royal Society of Canada, 5-66. (Special Publications 12.)

Senneset, K. and N. Janbu. 1985. Shear strength parameters obtained from static cone penetration tests. In Chaney, R. C. and K. R. Demars, eds. Strength testing of marine sediments: laboratory and in-situ measurements. Philadelphia, PA, American Society for Testing and Materials, 41-54. (Special Technical Publication 883.)

Senneset, K., N. Janbu and G. Svano. 1982. Strength and deformation parameters from cone penetration tests. In Verruijt, A., F.L. Beringen and E.H. de Leeuw, eds. Penetration testing. Proceedings of the Second European Symposium on Penetration Testing, Amsterdam, May 24 27, 1982. Vol. 1. Rotterdam, A. A. Balkema, 863-870.

Skempton, A. W. 1985. Residual strength of clays in landslides, folded strata, and the laboratory. Géotechnique, 35, 3-18.

The accuracy of references in the text and in this list is the responsibility of the authors, to whom queries should be addressed.

\section{APPENDIX}

The bed-parallel force on the leeward cone, $F_{1}$, is negligible relative to $F_{\text {cr. }} . F_{1}$ depends on the stress that till exerts normal to the cone surface, $N^{\prime}$. The bed-parallel component of $N^{\prime}$ pushes forward on the fish, and friction between the till and cone surface provides resistance. Balancing these forces gives

$$
F_{1}=A_{\mathrm{cs}} N^{\prime}\left(\cos \alpha \tan \phi_{\mathrm{s}}-\sin \alpha\right)
$$

where $A_{\text {cs }}$ is the surface area of the cone and $\tan \phi_{8}$ is the friction coefficient for till sliding over steel. To maximize $F_{1}$, assume that $N^{\prime}=\sigma_{\mathrm{m}}^{\prime}=\sigma_{\mathrm{p}}^{\prime}$. Dividing by Equation (4) then yields a maximum estimate for $F_{1} / F_{\mathrm{cr}}$ :

$$
\frac{F_{1}}{F_{\mathrm{cr}}}=\frac{A_{\mathrm{cs}}}{A_{\mathrm{c}}}\left(\frac{\cos \alpha \tan \phi_{\mathrm{s}}-\sin \alpha}{N_{\mathrm{F}}}\right) .
$$

Simple experiments in which a loaded steel plate was dragged across till from Storglaciären yielded $\phi_{\mathrm{s}}=28^{\circ}$. $A_{\mathrm{cs}} / A_{\mathrm{c}}=2.8$ and $N_{\mathrm{F}}=15$ (Equation (3) with $\phi=$ $\phi_{\mathrm{r}}=31^{\circ}$ and $\left.\beta=15^{\circ}\right)$. Thus, $F_{\mathrm{l}} / F_{\mathrm{cr}}<0.03$. 